\title{
COMPARING SERVICE QUALITY IN PUBLIC VS PRIVATE DISTANCE EDUCATION INSTITUTIONS: EVIDENCE BASED ON MALAYSIA
}

\author{
Dr. Fazelina Sahul HAMID \\ ORCID: https://orcid.org/0000-0002-9140-9789 \\ School of Distance Education \\ Universiti Sains Malaysia, Malaysia \\ Dr. Nick YIP \\ ORCID: https://orcid.org/0000-0003-4550-8994 \\ Norwich Business School \\ University of East Anglia \\ Norwich, United Kingdom
}

Received Date: 04/04/2018 Accepted Date: 15/05/2018

\begin{abstract}
Assessment of the quality of distance education institutions has become an important issue that needs to be addressed to ensure program survival. This study uses SERVPERF model to identify the differences that exists in students' perception of service quality in public and private universities in Malaysia that offer distance education. Our study confirms that this model is valid and reliable. We find that the students' overall perception of service quality is lower in all five dimensions of service quality for the private universities. The dimensions that influence overall service quality are noticeably different for public and private universities. This suggests that private universities need to improve their service provision in order to remain competitive. Managerial implications of the major findings are discussed.
\end{abstract}

Keywords: Service Quality, SERVPERF model, distance education; higher learning institutions.

\section{INTRODUCTION}

The education sector in Malaysia has long been dominated by the public universities that have been mainly funded by tax payers' money. However, public universities in Malaysia are not able to meet the increasing demand for higher education locally. Private higher education institutions (HEIs) are established to meet the rising demand for tertiary education in Malaysia. The higher education industry was liberalized in 1996 with the introduction of the Private Higher Educational Institutional Act (PHEIA). This resulted in the proliferation of private higher education institutions (HEIs) in Malaysia. Privatization of higher education has been shown to offer customers more choices, increase competition, improve economic efficiency and reduce the financial burdens of the governments (Wilkinson \& Yussof, 2005). Currently, there are 20 public universities, 26 private universities, 405 public skill training institutes and 584 private skill training institutes in Malaysia that offer a wide variety of courses. Enrolment in HEIs increased from 649,000 in 2005 to 1,156,293 in 2013. Almost 42 percent of the total enrolment in 2013 is accounted for by the private HEIs. Given the importance of private HEIs in the Malaysian education sector, this study seeks to identify the level of service quality that they offer and compare it that of the public HEIs that have long standing history in Malaysia. 
The issue of quality in HEIs has long been addressed through course review and accreditation (Huang, 2007). In line with this, the Malaysian Qualifications Agency (MQA) was established in 2007 to ensure that public and private institutions share the same quality control measures. However, under the concept of service dominant logic where actors are resource integrators, delivering a service requires more than managing resources or understanding processes to ensure that regulations are in place to meet the demands of the student. Essentially, HEIs need to recognize that the interactions between service providers and consumers are also critical in creating value for both parties. Angell et al. (2008) asserts that universities should shift from the traditional routes of assessment and reviews that is product led to assessments that it customer focused. Service quality assessment can provide HEIs valuable insights that can be used to improve program quality and justify resource allocations. Universities can use service quality as a tool to attract students and generate revenue. Students' choice of HEI has been shown to depend on their perception of service quality (Donaldson \& McNicholas, 2004; Raemah \& Rosli, 2011; Taner \& Antony, 2006). Given the fact that students in Malaysia have to pay more for their education now and have wider options to choose from, the HEIs need to ensure that the services that they provide meet students' expectations.

Even though service quality is important for the survival of both public and private institutions, its principles have been implemented at a faster rate in private institutions compared to the public ones (Agus et al., 2007). The public sector have been mostly influenced by political authorities and bureaucratic agencies (Caemmerer \& Dewar, 2013). As such it it less focused in meeting customers expectatioans. Kadir et al. (2000) confirms that less focus has been given to issues relating to service quality in the Malaysian public sector. Nevertheless, exploratory study conducted by Agus et al. (2007) on the Malaysian public sector confirms the benefits of improving service quality to customers. This is very relevant for all the public universities in Malaysia that have become less reliant on public funding since their corporatisation in 1998. In addition to focusing on teaching and research, these insitutions have adopted the service culture which is practiced by the private entities to remain competitive (Terpstra \& Honoree, 2009).

Private HEIs are established to meet the rising demand for tertiary education in the existing fields of studies and alternative field of studies which offers high employment opportunities. They are mainly driven by profit. Even though private enterprise are known to offer higher quality compared to the public ones, the proposition that private HEIs offer better quality than the public ones is debatable (James \& Benjamin, 1988; Tilak, 1991). Romero \& Rey (2004) asserts that public HEIs are associated with higher quality compared to the private ones because they are able to atract the best students. Raemah \& Rosli (2011) finds that academic staff at the public universities in Malaysia have higher level of commitment to service quality compared to those from the private ones. On the other hand, Wilkinson \& Yussof (2005) finds that private HEIs in Malaysia incur lower per student expenditure, have higher student to staff ratio, employ less qualified staff and spent less on improving physical facility. Nevertheless, their costs minimization strategy could happen at the expense of service quality. This raises valid questions about the quality of services offered by private HEIs in Malaysia.

Most of the existing studies on service quality in Malaysian HEIs have focused on traditional setting that mainly involves face-to-face classroom teaching (Abdullah, 2006; Jusoh et al., 2004; Zaibaf et al. 2013). Nevertheless, the demand for distance education has increased over the years due to cost effectiveness, convenience, flexibility and use of different delivery mode (Ancis, 1998; Burke, 1998). Distance education has made university courses and programs more accessible to learners. Distance education in Malaysia was pioneered by Universiti Sains Malaysia (USM) with the establishment of its Centre for Off-Campus Studies in 1971. As at 2015, there were 23,041 students enrolled in distance education programs in eight public HEIs. Private HEIs in Malaysia also started offering distance education programs to meet the rising demand for higher education among working 
adults. With more than 100,000 students, Open University Malaysia (OUM) is currently the leading provider of distance education in Malaysia. Increasing number of students is also enrolled in the other five private HEIs that offers distance education programs.

Despite gaining popularity, not much research has been done on issues relating to service quality in distance education in Malaysia. Studies by Sim \& Idrus (2003), Poon et al. (2004), Rashid \& Latif (2004), San (2010) and Hilmi \& Ali (2012) on service quality in the Malaysian distance education have mainly focused on issues related to student satisfaction, effectiveness of distance learning process, effect of service quality on the intention to complete studies and distance learners' perception of service quality and ease-of-use of the Learning Management System (LMS). Even though these studies have looked at issues relating to service quality, none of them have made comparison between students perception of service quality delivered by public and private DEIs.

This study aims to fill in the gap in the existing literature by analyzing students' perception of service quality in distance education. More specifically, it aims to compare students' perception of service quality offered by public and private distance education institutions (DEIs) in Malaysia. The theoretical model by Romero \& Rey (2004) postulates that public HEIs offer higher quality compared to the private ones in equilibrium. This happens mainly because they offer cheaper fees and attract more qualified students compared to the private HEIs. The observation across European countries supports this theory. This study aims to test this theory in the Malaysian DEIs setting. This analysis of this study will be done based on the survey response of distance education students at two public funded universities and two private universities in Malaysia. The findings of this study can help understand what customers' value. More importantly, it can provide valuable insights to the providers of DEIs in emerging countries.

\section{LITERATURE REVIEW}

The development of quality management was only given some kind of importance in the service sector in the 1990s (Vinzant, 1996). Quality management in the service sector was fast becoming an important element in the service delivery process as customer feedback provided a platform for improvement which lead to higher customer satisfaction and increased revenues. One aspect of customer feedback was focused on trying to understand the customers' perspective of the service quality received. However, measuring service quality is a daunting task compared to measuring product quality given its intangible, heterogeneity, inseparability and perishability characteristics. Service marketing literature commonly uses perceived quality in trying to measure service quality. Unlike objective quality that is derived based on the actual technical superiority or excellence of the product, perceived quality is derived based on consumer's judgement of the product's overall superiority or excellence (Zeithaml, 1988). The process of standardizing identical services is more difficult because an identical service could be rendered in a different way by different members of the employees to different users of the service at the same time, but more importantly it can be conceived differently by the consumers. The case is no different for services delivered by in HEIs (Woodall, Hiller, \& Resnick, 2014).

Existing literature offers various definition of service quality in higher education (Jain et al, 2011). Crosby (1979) defines it as avoidance of defect in education while Peters et al. (1982) defines it as excellence in education. Parasuraman et al. (1985)defines it as meeting or exceeding customer's expectation. British Quality Standard (BQS) defines it as the ability to live up to the stakeholders' requirements and meet their expectations (Brookes \& Becket, 2007). Service quality has been shown to influence customer satisfaction and customer loyalty (Tayyab \& Rajput, 2014) and contribute towards higher long-term profitability (Zeithaml et al., 2006). 
Bateson (1977) highlights the importance of service quality to HEIs. He asserts that in depth knowledge about students' perceptions of service quality enable HEIs to deliver excellent customer service. Students are able to differentiate the quality of services offered by HEIs (Carrilat, Jaramillo, \& Mulki, 2009). Hence, any measures taken to improve the education system by taking into account of students' feedback will improve the outcome quality (Glasser, 1990).

In the case of "Distance Education", one significant perspective of education research focuses on the vital role of the student as a co-producer of their own education and how this role, where students are required to invest operand (tangible) and operant resources (non-tangible), might impact on the commercialization of higher education (Molesworth, Nixon, \& Scullion, 2009; Tapscott \& Williams, 2010). For example, studies have shown that in order for learning to occur, high levels of student participation and intellectual effort by the students, in and outside their classes, are required (Syson, 2008). Arising from these arguments, studies in relation to the students' perspective on "perceived quality" of their university experience (Lizzio, Wilson, \& Simons, 2002; Picciano, 2002), "expectations" of the different stakeholders within the university (Sander, Stevenson, King, \& Coates, 2000; Telford \& Masson, 2015), the relevant "information and processes" needed to assist in their university experience (Eisenberg \& Small, 1993), the perceived level of "confidence" required to fulfil their objectives in co-creating their education (Sander \& Sanders, 2003), the impact of social activities on the student experience (Le Blanc \& Nguyen, 1999), the perceived different "learning" processes that encourages students' intellectual growth and the "authority and "empowerment" necessary to aid students in facing the challenges of a university education (Cook-Sather, 2002; Kotze \& Plessis, 2003; Redding, 2005) might impact on the overall service delivery.

These studies then appear to be strategically important as it informs universities on the students' overall perception of themselves, their intellectual inputs and commitment to their studies for obtaining their respective qualifications. Additionally, this area of research appears to provide insights into the student's level of expectations of the university (Lizzio et al., 2002; Voss, Gruber, \& Szmigin, 2007) and the services that universities provide in order to support active student participation and interaction as an important element in the student's overall university experience (Cook-Sather, 2002; Picciano, 2002). More significantly, these studies provide a critical link for university administrators as they impact on overall student satisfaction, a key influence on both students' and parents' opinions when applying for places at universities (Douglas, Douglas, $\&$ Barnes, 2006). Also, universities are increasingly focusing on this area as they re-engineer their organizations to not only adapt to student needs, but to also develop a system for continuously monitoring how effective they are in meeting or exceeding student needs in order to remain competitive (Elliott \& Shin, 2002).

Existing service marketing literature offers various models in measuring service quality. Among the models have evolved in the literature are the Gronroos model (Gronroos, 1983), SERVQUAL model (Parasuraman et al., 1985), SERVPERF model (Cronin Jr \& Taylor, 1992), Importance-performance analysis (IPA) (Ford et al. 1999) and INDSERV model (Gounaris, 2005). All of these models measure service quality from different perspectives using dimensions that differ according to the schools of thought, industries, service type, culture or firms operating in same industry (Sultan \& Wong, 2010). SERVQUAL model is the most famous model in measuring service quality. This model measures quality by comparing customers' service perception with expectations. For the most parts, other models are extensions or adaptations of SERVQUAL model (Buttle, 1996). Nevertheless, the applicability of this model in measuring service quality in higher education setting has been questioned due to the lack of prior knowledge and experience (Chapman, 1979), potential inappropriateness of the five dimensions (Carman, 1990; Cronin \& Taylor, 1992) and the inability of expectations to remain constant over time (Carman, 1990). 
The SERVPERF model proposed by (Cronin Jr \& Taylor, 1992) is a simple and straight forward approach to measure service quality based only on customers' perception. They show that it produces better results, more reliable estimations, greater convergent and discriminant validity, greater explained variance and less bias than the SERVQUAL. Existing literature offers mixed results when comparing both models. Studies by Furrer et al. (2000), Jain \& Gupta (2004) and Bayraktaroglu \& Atrek (2010) find that SERVQUAL scale is better at measuring service quality while studies by Brochado (2009), Moisescu \& Gica (2013) and Park \& Ha (2013) find that SERVPERF is better. However, the decision to choose between the two models should not be based only on the results. Dabholkar et al. (2000) argues that it should be based on the purpose of the study. SERVPERF should be used if the study aims to find the determinants of service quality whereas SERVQUAL should be used if the study aims to find the gap between customers' expectation and perception. Devlin et al. (2002) assert that SERVPERF is sufficient in measuring service quality because customers' judgement of service quality is often based on their expectations.

\section{THEORETICAL BACKGROUND AND HYPOTHESES DEVELOPMENT}

The key aim of this study is to measure students' perception of service quality offered by private and public HEEIs in Malaysia. In line with studies by Abdullah (2006), Brochado (2009) and Hui-feng (2010), this study will use SERVPERF model in measuring service quality. Sultan \& Wong (2010) postulates that SERVPERF scale outperforms SERVQUAL scale in the context of higher education because the former explains more of the variation in customer's satisfaction than the latter. The SERVPERF model uses the dimensional approach in measuring service quality. This approach focuses on service features and requires customers to rate them based on their perception.

Similar to the SERVQUAL model, the SERVPERF model uses 23 perception items that are grouped into five dimensions. These dimensions are reliability, responsiveness, assurance, empathy and tangibles. Reliability measures the service providers' ability to perform the promised service dependably and accurately. Responsiveness measures the service providers' ability to assist and provide prompt service. Assurance measures the service providers' ability in ensuring that employees are knowledgeable, courteous, and able to convey trust and confidence to customers on the service offered. Empathy measures the caring and individualized attention that the service provider offers to its customers. Tangibility takes into account of the appearance of physical facilities, equipment, personnel, and communication materials. These dimensions have been successfully used by Rigotti \& Pitt (1992), Abdullah (2006), Brochado (2009) and Hui-feng (2010) to measure service quality in higher education setting.

DEIs are different compared to the traditional HEIs as they mainly involve in learning groups which are separated and rely more on the use interactive telecommunications systems to connect learners, resources, and instructors (Simonson, Schlosser, \& Orellana, 2011). As a result, different dimensions need to be used in measuring service quality in DEIs (Stodnick \& Rogers, 2008 and Udo et al., 2011). The perceived service quality evaluation models that are used for the traditional HEIs need to be modified since they take into account of the direct interpersonal interactions and tangible elements such as premises, facilities, and service staff which are less relevant in the case of distance education. In line with Stodnick \& Rogers (2008) and Udo et al. (2011), the fifth dimension of SERVPERF is modified to take into account of physical and online appearance of the service.

The present study aims to identify the dimensions that affect service quality in DEIs. More specifically, this study aims to address the following research questions: 
Is the SERVPERF model suitable in measuring service quality in DEIs?

$>$ Are there differences in the level of services offered by public and private DEIs?

$>$ Are there differences in the antecedents of overall service quality provided by public and private DEIs?

The following hypotheses are tested in this study:

$>\mathrm{H} 1$. There is a significant difference in students' perception of the "Reliability" of services provided by public and private DEIs.

$>\mathrm{H} 2$. There is a significant difference in students' perception of the "Responsiveness" of services provided by public and private DEIs.

$>\mathrm{H} 3$. There is a significant difference in students' perception of the "Assurance" of services provided by public and private DEIs.

$>$ H4. There is a significant difference in students' perception of the "Empathy" of services provided by public and private DEIs.

$>\mathrm{H} 5$. There is a significant difference in students' perception of the "Facility" of services provided by public and private DEIs.

$>$ H6. There is a significant difference in the antecedents of overall service quality in the public and private DEIs.

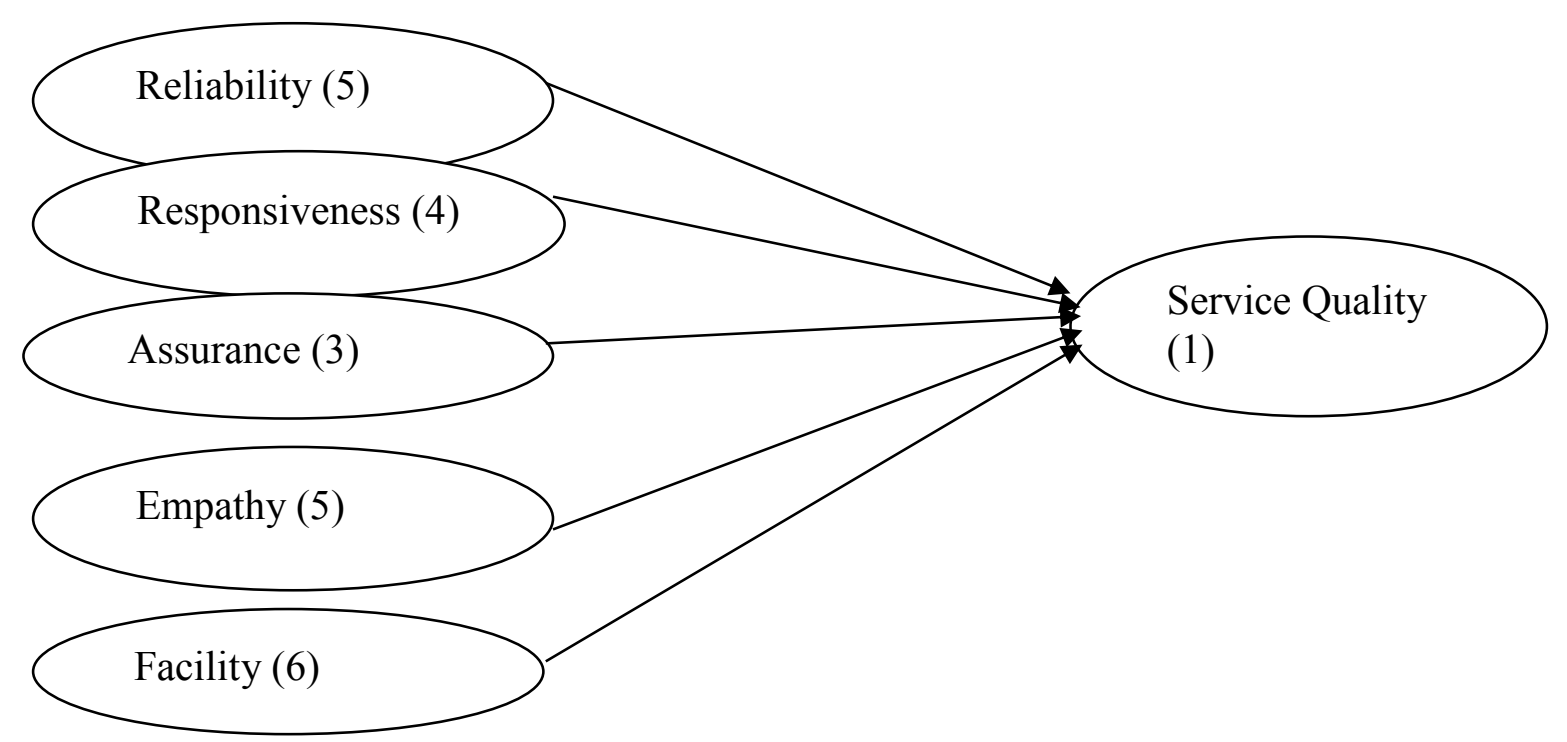

Figure 1. Service quality model: SERVPERF

\section{METHODOLOGY}

This study employs a quantitative methodology, employing two main statistical tools; factor analysis and regression analysis. While factor analysis was used to assist with understanding the student's perspective of service quality, regression analysis was applied to identify the dimensions that affect service quality in distance education. All of the items used to measure the five SERVPERF dimensions are adapted from the study by Parasuraman et al. (1988) and previous theoretical research in education covering broad aspects such as learning processes (academic success), interactions, engagements, information gathering (administrative actions such as registration, library), building relationships, social activities and confidence. However, the wording is altered to 
suit a distance education setting. A 7-point Likert item is used for measuring the five constructs. In total, 23 perceptual measures were adapted to assist with understanding the student's perspective of their university experience with regards to the dimensions of service quality. To ensure that these measures were appropriate, the professional opinions of two higher education academics were consulted to check for content validity of the items and scales. Both experts had similar consensus that the source of literature and the measures were appropriate and valid.

\section{Data Collection}

Participants in this study are students from DEIs in Malaysia. Based on the National Education Statistics released by the Malaysian Ministry of Education in 2014, there are 14 HEIs that offer distance education in Malaysia. The selection of DEIs for this study is made according to two criteria. First, only DEIs that use "blended learning" approach that incorporates both online and face-to-face interactions between instructors and students are chosen. Secondly, only DEIs that offer degree programs are chosen. Based on these criteria, two private and two public DEIs that are among the oldest in the country are chosen. These institutions provide the best platform for seeking the participants' opinions about their respective education experiences. The selfadministered questionnaire is posted on the DEIs' online student portal. Participations are based on voluntary basis. This process yielded a total of 720 questionnaires. A total of 640 questionnaires have complete responses. The descriptive statistics of the students are presented in Table 1.

\section{Data Analysis}

\section{Measurement Model}

The scales used in this study have been well established in previous literature. Hence, a confirmatory factor analysis approach is carried out using SmartPLS to assess the validity and reliability of the data. The SERVPERF model consists of 23 items describing five dimensions: reliability, responsiveness, assurance, empathy and facility. The measurement model is assumed to be fit for model testing if it is reliable and valid. The latter is tested by verifying the convergent and discriminant validity while the former is tested by verifying the reliability. According to Fornell \& Larcker (1981) convergent validity can be verified using three criteria: the factor loading for individual items is more than 0.50 , the average variance extracted (AVE) are above 0.50 and the composite reliability (CR) of all the constructs is above 0.80 . Results in Table 2 show that that all of the above criteria are fulfilled. This conforms that the convergent validity of the measurement model is verified.

Table 1. Respondent background for public and private DEIs

\begin{tabular}{ll}
\hline Type of Institution & Public (39\%) \\
\hline Gender & Male (34\%); Female (66\%) \\
Age & $<25(4 \%) ; 25<>35(74 \%) ; 36<>45(16 \%) ;>45(6 \%)$ \\
Education Level & SPM $(10 \%) ;$ STPM $(20 \%) ;$ Diploma $(65 \%) ;$ Degree (5\%) \\
Year of Study & 1st (3\%); 2nd (33\%); 3rd (33\%); 4th (24\%); 25 th (7) \\
Employment & Full time (90\%); Part time (8\%); Unemployed (3\%) \\
Income & $<$ RM2500 (48\%); RM2501<>RM5000 (47\%); RM5001 (5\%) \\
& Beginner (1\%); Basic user (38\%); Intermediate user (49\%); \\
Computer literacy & Advance (21\%) \\
& \\
\hline Type of Institution & Private (61\%) \\
\hline Gender & Male (42\%); Female (58\%) \\
Age & $<25(21 \%) ; 25<>35(42 \%) ; 36<>45(29 \%) ;>45(8 \%)$
\end{tabular}




\begin{tabular}{ll} 
Education Level & SPM (27\%); STPM (13\%); Diploma (52\%); Degree (8\%) \\
Year of Study & 1st (25\%); 2nd (22\%); 3rd (17\%); 4th (24\%); $\geq 5$ th $(13)$ \\
Employment & Full time (83\%); Part time (10\%); Unemployed (7\%) \\
Income & < RM2500 (50\%); RM2501<>RM5000 (37\%); $\geq$ RM5001 (13\%) \\
Computer literacy & Beginner (2\%); Basic user (30\%); Intermediate user (60\%); Advance (8\%) \\
\hline
\end{tabular}

Discriminant validity is verified by observing the correlations between variables. A construct is considered different if the AVE is greater than their shared variance. Anderson \& Gerbing (1988) asserts that the square root of the AVE for a given construct should be greater than the absolute value of the standardized correlation of the given construct with any other construct in the analysis. Results in Table 3 verify the discriminant validity of the measurement model. The reliability of the data is verified using Cronbach Alpha coefficient. Results in Table 2 confirm that the Cronbach alpha's value for all the constructs is above 0.89 , well above the minimum acceptable value of 0.80 (Gliem \& Gliem, 2003).

Table 2. Convergent and discriminant validity

\begin{tabular}{|c|c|c|c|c|}
\hline Quality Dimensions & $\begin{array}{c}\text { Standard } \\
\text { Loading }\end{array}$ & $\begin{array}{l}\text { Average } \\
\text { Variance } \\
\text { Extracted } \\
(>0.50)\end{array}$ & $\begin{array}{c}\text { Composite } \\
\text { Reliability } \\
\quad(>0.7)\end{array}$ & $\begin{array}{l}\text { Cronbach } \\
\text { Alpha } \\
(>0.8)\end{array}$ \\
\hline Reliability & & 0.75 & 0.94 & 0.92 \\
\hline The university provides services as promised. & 0.865 & & & \\
\hline The university provides dependable services. & 0.875 & & & \\
\hline The university performs services right the first time. & 0.893 & & & \\
\hline The university provides services at the promised time. & 0.883 & & & \\
\hline The university maintains error-free records. & 0.781 & & & \\
\hline Responsiveness & & 0.75 & 0.92 & 0.89 \\
\hline The university keeps students informed about when services will be performed & 0.823 & & & \\
\hline The university provides prompt service to students. & 0.899 & & & \\
\hline The university is willing to go out if its way to help students. & 0.877 & & & \\
\hline The university is always ready to respond to students' request. & 0.881 & & & \\
\hline Assurance & & 0.82 & 0.93 & 0.89 \\
\hline The university staff makes students feel safe in their transactions. & 0.883 & & & \\
\hline The university staffs are consistently courteous. & 0.922 & & & \\
\hline The university staffs have the knowledge to answer students' questions. & 0.901 & & & \\
\hline Empathy & & 0.77 & 0.94 & 0.93 \\
\hline The university gives students individual attention. & 0.849 & & & \\
\hline The university deals with students in caring fashion. & 0.857 & & & \\
\hline The university has students' best interest at heart. & 0.884 & & & \\
\hline The university understands the need of the students. & 0.896 & & & \\
\hline The university is genuinely concerned about the students. & 0.895 & & & \\
\hline Facility & & 0.77 & 0.95 & 0.94 \\
\hline The university has visually appealing facilities. & 0.839 & & & \\
\hline The university has LMS* that provides useful information. & 0.898 & & & \\
\hline The university has LMS that provides accurate information. & 0.894 & & & \\
\hline The university has LMS that provides high quality information. & 0.903 & & & \\
\hline The university has LMS that provides visually appealing materials. & 0.893 & & & \\
\hline The university has staffs that have neat and professional appearance. & 0.826 & & & \\
\hline
\end{tabular}

* Learning Management System 


\section{Mean Comparison}

Table 3 shows that the means for all 23-items measuring service quality perceptions for public DEIs are above 4.75. The lowest mean of 4.76 is recorded for "maintaining error-free records" while the highest mean of 5.43 is recorded for "useful information in learning management system". Among the five dimensions, students' perception of public DEIs service quality is highest for Facility. Within that dimension, highest perception relates to the learning management system. On the other hand, students' perception of public DEIs service quality is lowest for Empathy. More specifically, students perception is lowest relating to the type of attention that that they receive. Hence, public DEIs need to work on providing more individualized attention to students. The means for all 23-items measuring service quality perceptions for private DEIs are above 4.3. The lowest mean of 4.41 is recorded for "maintaining error-free records" while the highest mean of 5.43 is recorded for "making students feel safe in their transactions". Even though students' perception of private DEIs service quality is highest for Assurance compared to other dimensions, it is lower than students' perception of public DEIs service quality for Assurance. Students' perception of private DEIs service quality is lowest for Reliability. This suggests that private DEIs need to improve their service by making it more dependable and accurate. In general, the private DEIs also need to improve its services on a number of other areas. Among others, they need improve on their willingness and readiness to respond to students' request. They also need to ensure that their staffs are capable in responding to students queries. Private HEIs also need to improve on the caring and individualized attention that they give to student. Even though private HEIs fare better in the Facility dimension, they need to ensure that the online and offline facilities that they offer are more appealing to students.

Table 3. Mean comparison

\begin{tabular}{|c|c|c|}
\hline & \multicolumn{2}{|c|}{ Mean values } \\
\hline & Public & Private \\
\hline \multicolumn{3}{|l|}{ Reliability } \\
\hline The DEI provides services as promised. & 5.26 & 4.80 \\
\hline The DEI provides dependable services. & 5.13 & 4.79 \\
\hline The DEI performs services right the first time. & 5.08 & 4.78 \\
\hline The DEI provides services at the promised time. & 5.12 & 4.85 \\
\hline The DEI maintains error-free records. & 4.76 & 4.41 \\
\hline \multicolumn{3}{|l|}{ Responsiveness } \\
\hline The DEI keeps students informed about when services will be performed. & 5.32 & 5.09 \\
\hline The DEI provides prompt service to students. & 5.15 & 4.79 \\
\hline The DEI is willing to go out if its way to help students. & 5.12 & 4.78 \\
\hline The DEI is always ready to respond to students' request. & 5.18 & 4.83 \\
\hline \multicolumn{3}{|l|}{ Assurance } \\
\hline The DEI staff makes students feel safe in their transactions. & 5.21 & 5.15 \\
\hline The DEI staffs are consistently courteous. & 5.09 & 5.05 \\
\hline The DEI staffs have the knowledge to answer students' questions. & 5.31 & 4.96 \\
\hline \multicolumn{3}{|l|}{ Empathy } \\
\hline The DEI gives students individual attention. & 4.87 & 4.69 \\
\hline The DEI deals with students in caring fashion. & 4.83 & 4.72 \\
\hline The DEI has students' best interest at heart. & 5.10 & 4.81 \\
\hline The DEI understands the need of the students. & 5.13 & 4.76 \\
\hline The DEI is genuinely concerned about the students. & 5.08 & 4.80 \\
\hline \multicolumn{3}{|l|}{ Facility } \\
\hline The DEI has visually appealing facilities. & 5.09 & 4.79 \\
\hline The DEI has learning management system that provides useful information. & 5.43 & 5.08 \\
\hline The DEI has learning management systems that provides accurate information. & 5.41 & 5.07 \\
\hline The DEI has learning management systems that provides high quality information. & 5.32 & 5.05 \\
\hline The DEI has learning management systems that provides visually appealing materials. & 5.19 & 4.80 \\
\hline The DEI has staffs that have neat and professional appearance. & 5.33 & 5.08 \\
\hline
\end{tabular}




\section{Hypothesis Testing}

Test of Difference - Comparison of Public and Private DEls

Independent t-tests are performed to compare public and private DEIs' students' perceptions of the five dimensions of service quality proposed by the SERVPERF model. The results of this analysis are summarized in Table 4. The results reveal that students from public DEIs and private DEIs differ in their perception level of the five dimensions of service quality. More specifically, we find that students' perceptions of the five dimensions of service quality is significantly lower for the private DEIs compared to the public DEIs. The mean score for reliability, responsiveness, assurance, empathy and facility is significantly different for public and private HEIs supporting hypotheses 1 to 5 . Before running the regression analysis, we performed a Chow test to analyse the influence of five antecedents of overall service quality among the public and private DEIs' students. This is done by comparing the regressions using pooled and two non-pooled samples (Chiu \& Hofer, 2015; Chow, 1960). The Chow test statistics is calculated based on the following method:

$$
\frac{\left[R S S_{p}-\left(R S S_{1}+R S S_{2}\right)\right] / k}{\left[\left(R S S_{1}+R S S_{2}\right) /(n-2 k)\right]}
$$

In this case, RSSp is the residual sum of squares of the pooled sample regression, RSS1 is the residual sum of squares of the public DEIs sample regression, and RSS2 is the residual sum of squares of the private DEIs sample regression. The parameter $n$ is the number of observations while $k$ is the number of parameters. We obtained a $F$-value of 2.92. The $F$-table of critical values displays a cut-off value of $F(0.05,6,640)=2.11$. Since the $F$ value is greater than the critical value, this result confirms that there are significant differences between the public and private DEIs samples. As a results, performed separate regression analyses for each sample group.

Table 4. Hypotheses testing

\begin{tabular}{lcccc}
\hline & \multicolumn{2}{l}{ Mean values } & & \\
& Public & Private & $\mathrm{t}$ & Sig. (2-tailed) \\
\hline Reliability & 5.0704 & 4.7271 & 5.148 & .000 \\
Responsiveness & 5.1949 & 4.8764 & 4.705 & .000 \\
Assurance & 5.1994 & 5.0487 & 2.096 & .036 \\
Empathy & 4.9988 & 4.7757 & 3.142 & .002 \\
Facility & 5.2924 & 4.9734 & 4.808 & .000 \\
& & & & \\
\hline
\end{tabular}

\section{Regression Analysis}

We used linear regression to test the relationship proposed by the SERVPERF model. The regression analysis are carried out separately for public and private DEIs in order to assess the relative impact of the five SERVQUAL dimensions on the overall perception of service quality. The model summary statistics display a good fit for the public DEIs $\left(R^{2}=0.441\right)$ sample with 44.1 percent of the variance in overall service quality explained by the model. The analysis of variance (ANOVA) shows that the overall model is statistically significant $(\mathrm{p}<0.05)$. The variance inflation factors $(\mathrm{VIF})$ values are all well below ten and as a result the multicollinearity concerns can be ruled out for this model (Myers, 1990). The results in Table 5 show that Empathy does not exert significant influences on the overall service quality of public DEIs. The findings also show that of the four variables that significantly influence the overall service quality, Reliability is the most 
influential coefficient $(\beta=0.299, \mathrm{p}<0.05)$. This result is followed by Responsiveness which accounts for 19.6 percent of total variance in overall service quality. Assurance and facility also have significant influence on overall service quality.

The SERVPERF model explains $68.5 \%$ of the variance in overall service quality of private DEIs $\left(R^{2}=0.685\right)$. The ANOVA indicates that the overall model is statistically significant $(\mathrm{p}<0.05)$ and VIF results confirm that multicollinearity concerns can be ruled out. The results show that assurance and facility do not exert significant influence on the overall service quality of private DEIs. Reliability accounts for 57.5 percent of total variance in overall service quality $(\mathrm{p}<0.05)$. On the other hand, responsiveness and empathy account for 15.6 percent and 12.8 percent of the variance in overall service quality.

Overall, our findings suggest that the SERVPERF model explain higher percentage of variance in overall service quality of private DEIs compared to public DEIs. The results also illustrate that there are significant differences with regard to the antecedents of overall service quality in the public and private DEIs, supporting hypothesis H6. The public DEIs need to focus on the dimensions of services quality that relates to reliability, responsiveness, assurance and facility to enhance students' overall perception of service quality. On the other hand, the private DEIs need to focus on the dimensions of services quality that relates to reliability, responsiveness and empathy to enhance students' overall perception of service quality.

Table 5. Regression analysis

\begin{tabular}{l|rrr|rrr}
\hline & \multicolumn{3}{|c|}{ Public (adjusted R square $=0.441)$} & \multicolumn{4}{|c}{ Private (adjusted R square $=0.685)$} \\
& Beta & $\mathrm{t}$ & $\mathrm{sig}$ & Beta & \multicolumn{1}{c}{$\mathrm{t}$} & \multicolumn{1}{c}{ sig } \\
\hline Reliability & .299 & 3.524 & .001 & .575 & 8.654 & .000 \\
Responsiveness & .196 & 1.944 & .053 & .156 & 2.015 & .045 \\
Assurance & .166 & 1.957 & .052 & -.076 & -1.286 & .199 \\
Empathy & -.082 & -.972 & .332 & .128 & 1.854 & .064 \\
Facility & .160 & 2.042 & .042 & .059 & 1.005 & .316 \\
& & & & & & \\
\hline
\end{tabular}

\section{DISCUSSION AND CONCLUSION}

Rising demand for distance education services among working adults in Malaysia is in line with the aspirations of the government in enculturating lifelong learning among its citizens. This has increased the number of DEIs in Malaysia and is seen as a necessary reason to investigate the quality of the service offered by these institutions. Distance education service provider and the consumers are very much reliant on each other to create value. Even though universities have their own benchmark to measure the quality of their services, this may not necessarily be aligned with students' perception of the DEIs' service quality. Hence, it is vital for us to explore how students perceive the quality of the service provided by the DEIs. In addition, greater participation by private entities in providing distance educational services provide a valid motivation for this study to compare students' perception of service quality delivered by public and private DEIs.

Overall, we find that students' perception of service quality is lower for private DEIs compared to public DEIs. We find that the SERVPERF model is able explain higher percentage of the variations in overall service quality of private DEIs compared to public DEIs. Our findings also imply that the impact of SERVPERF construct on the overall perception of service quality varies, based on the type of institutions which are assessed. These 
findings have several implications. Firstly, private DEIs in Malaysia need to work on improving the quality of their services. This is essential in ensuring that they are able to compete with public DEIs in attracting more students. Secondly, the findings of this study support the assumptions that service quality perceptions differ significantly across type of institutions and highlight the need for a more differentiated view on service quality based on the institutional context. Thirdly, the findings of this study show that different dimensions need to be used to measure service quality according to the type of the business entity as stated by Sultan \& Wong (2010).

From a theoretical perspective, this study has raised a very pertinent question of "How does service quality perception vary under different institutional context?" This paper is among the earliest to validate the SERVPERF model in a public vs private distance educational context. The findings of this study also yield a number of managerial implications for distance education providers. Public DEIs need to ensure they provide reliable and responsive services. Managerial attention also need to be focused on ensuring that employees are knowledgeable, courteous, and able to convey trust and confidence to students on the service offered. In addition, they need ensure that due considerations are given to the physical and online aspects of the services. On the other hand, private DEIs need to ensure that the services that they offer to students are reliable, responsive and empathetic. An interesting finding of this study is that even though reliability of service is the most influential factor in predicting the overall service quality of both type of DEIs, its influence on private DEIs is almost double compared to public DEIs. Hence, this is a pertinent area that private DEIs need to focus on in improving students' perception of their service quality.

The cost of education at private HEIs is significantly higher compared to public HEIs. Despite the high fees that they charge, we find that they are not able to deliver better services to students. One of the possible reasons why this is happening could be due to the reasons why these institutions emerged in Malaysia. Private HEIs in Malaysia exist as a solution to capacity and accessibility issues. Most of the time, students are compelled to enter private HEIs because they don't have other options. In contrast, private HEIs emerged in countries like Indonesia and Bangladesh to provide more options for the students to choose from. Hence, they provide better service and are highly rated compared their public counterparts (Mazumder, 2014). Our findings suggest that private HEIs in Malaysia need to pay more attention to issues related to service quality. They can use this as a tool to attract more students not only from this country but also from abroad.

\section{LIMITATIONS AND FURTHER RESEARCH}

The findings of this study must be seen in light of its limitations. First, this study was only carried out in selected Malaysian DEIs. Generalising the results to other countries' education system should be done with caution. Second, this study is only focused on local students. Future research can expand it to include foreign students. Third, this study only looked at the suitability of the SERVPERF model in distance education setting, future research may expand this study by developing a broader conceptual model that influence perceived service quality in distance education.

Authors' Note: This work was supported by USM short term grant No: 304/PJJAUH/6312108. 


\section{BIODATA and CONTACT ADDRESSES of AUTHORS}

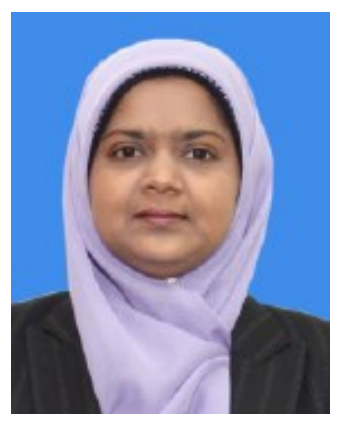

Fazelina Sahul HAMID is senior lecturer in Economics at the School of Distance Education, Universiti Sains Malaysia. Dr. Fazelina obtained her Ph.D. in Economics at the University Of Exeter, United Kingdom at July, 2012. Her research interest are in money and banking, international finance, behavioral finance and distance education. She has published more than 12 articles in international journals. She has also presented her research in various international conferences.

Dr. Fazelina Sahul HAMID

School of Distance Education

Address: Universiti Sains Malaysia, 11800, Minden, Malaysia

Phone: +604-6534552,

E-mail: fazelina@usm.my

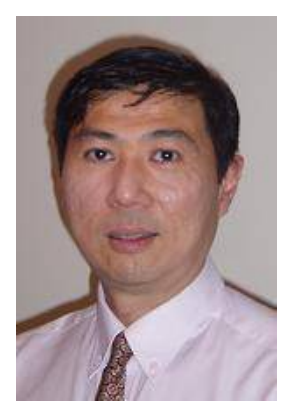

Nick YIP is a Lecturer in Marketing at the University of East Anglia's Norwich Business School. Prior to joining academia, he spent 18 years in industry within the service sector. Nick's research interests are in the areas of value co-creation and the pricing of services. Using the service dominant logic as a platform, he explores how value is co-created in between firms and the consumer/customer, and how these interactions may impact on pricing. Currently, he's exploring knowledge co-production between universities and industries. He has published in several business journals including Journal of Business Research, Industrial Marketing Management and International Journal of Small Business.

\section{Dr. Nick YIP}

Norwich Business School, Social Science Faculty

Address: University of East Anglia, Norwich Research Park, Norwich NR4 7TJ

Phone: +44 (0) 1603592185

E-mail: n.yip@uea.ac.uk

\section{REFERENCES}

Abdullah, F. (2006). Measuring service quality in higher education: three instruments compared. International Journal of Research \& Method in Education, 29(1), 71-89. https://doi.org/10.1080/01406720500537445

Agus, A., Barker, S., \& Kandampully, J. (2007). An exploratory study of service quality in the Malaysian public service sector. International Journal of Quality \& Reliability Management, 24(2), 177-190. https://doi.org/http://dx.doi.org/10.1108/02656710710722284

Ancis, J. R. (1998). Cultural competency training at a distance: Challenges and strategies. Journal of Counseling \& Development, 76(2), 134-143.

Anderson, J. C., \& Gerbing, D. W. (1988). Structural equation modeling in practice: A review and recommended two-step approach. Psychological Bulletin, 103(3), 411-423. 
Angell, R. J., Heffernan, T. W., \& Megicks, P. (2008). Service quality in postgraduate education. Quality Assurance in Education, 16(3), 236-254. https://doi.org/10.1108/09684880810886259

Bateson, J. (1977). Do We Need Service Marketing. Marketing Consumer Services: New Insights. Marketing Science Institute, Report, 77-115.

Bayraktaroglu, G., \& Atrek, B. (2010). Testing the superiority and dimensionality of SERVQUAL vs. SERVPERF in higher education. The Quality Management Journal, 17(1), 47-59.

Brochado, A. (2009). Comparing alternative instruments to measure service quality in higher education. Quality Assurance in Education, 17(2), 174-190.

Brookes, M., \& Becket, N. (2007). Quality management in Higher Education: A review of international issues and practice. International Journal of Quality and Standards.

Burke, J. (1998). The Internet Highway: A New Learning Tool for Accounting Students. New Accountant, $14(1)$.

Buttle, F. (1996). SERVQUAL: Review, critique, research agenda. European Journal of Marketing, 30(1), 832.

Caemmerer, B., \& Dewar, A. (2013). A comparison of private and public sector performance. Journal of Applied Business Research, 29(5), 1451-1458. Retrieved from http://www.scopus.com/inward/record.url?eid=2-s2.084887271883\&partnerID=40\&md5=112992ca3f0f0e5d57d058fed 1 bfe 841

Carman, J. M. (1990). Consumer perceptions of service quality: An assessment of the SERVQUAL dimensions. Journal of Retailing, 66(1), 33-55.

Carrilat, F. A., Jaramillo, F., \& Mulki, J. P. (2009). Examining the impact of service quality: a meta-analysis of empirical evidence. Journal of Marketing Theory and Practice, 17(2), 95-110.

Chapman, R. (1979). Pricing policy and the college choice process. Research in Higher Education, 10(37), 57.

Chiu, Y. T. H., \& Hofer, K. M. (2015). Service innovation and usage intention: a cross-market analysis. Journal of Service Management, 26(3), 516-538. https://doi.org/http://dx.doi.org/10.1108/JOSM10-2014-0274

Chow, G. C. (1960). Tests of Equality between Sets of Coefficients in Two Linear Regressions. Econometrica: Journal of the Econometric Society, 591-605.

Cook-Sather, A. (2002). Authorizing Students' Perspectives: Toward Trust, Dialogue, and Change in Education. Educational Researcher, 31, 3-14.

Cronin Jr, J. J., \& Taylor, S. A. (1992). Measuring service quality: a reexamination and extension. The Journal of Marketing, 55-68.

Crosby, P. B. (1979). Quality is Free. New York: McGraw Hill.

Dabholkar, P. A., Shepherd, C. D., \& Thorpe, D. I. (2000). A comprehensive framework for service quality: an investigation of critical conceptual and measurement issues through a longitudinal study. Journal of Retailing, 76(2), 139-73.

Devlin, J. F., Gwynne, A. L., \& Ennew, C. T. (2002). The antecedents of service expectations. The Service Industries Journal, 22(4), 117-136. 
Donaldson, B., \& McNicholas, C. (2004). Understanding the postgraduate education market for UK based students: a review and empirical study. International Journal of Nonprofit and Voluntary Sector Marketing, 9(4), 346-360. https://doi.org/10.1002/nvsm.259

Douglas, J., Douglas, A., \& Barnes, B. (2006). Measuring student satisfaction at a UK university. Quality Assurance in Education, 14, 251-267.

Eisenberg, M. B., \& Small, R. V. (1993). Information-based education: An investigation of the nature and role of information attributes in education. Information Processing \& Management, 29, 263-275.

Elliott, K. M., \& Shin, D. (2002). Student Satisfaction: an alternative approach to assessing this important concept. Journal of Higher Education Policy \& Management, 24, 197-209.

Ford, J. B., Joseph, M., \& Joseph, B. (1999). Importance-performance analysis as a strategic tool for service marketers: the case of service quality perceptions of business students in New Zealand and the USA. Journal of Services Marketing, 13(2), 171-186. https://doi.org/10.1108/08876049910266068

Fornell, C., \& Larcker, D. F. (1981). Evaluating Structural Equation Models With Unobservable Variables and Measurement Error. Journal of Marketing Research, 18(1), 39-50. https://doi.org/10.2307/3151312

Furrer, O., Liu, B. S.-C., \& Sudharshan, D. (2000). The Relationships between Culture and Service Quality Perceptions: Basis for Cross-Cultural Market Segmentation and Resource Allocation. Journal of Service Research, 2(4), 355-371. https://doi.org/10.1177/109467050024004

Glasser, W. (1990). The quality school: Managing students without coercion. New York: Perennial Library.

Gliem, J. A., \& Gliem, R. R. (2003). Calculating, interpreting, and reporting Cronbach's alpha reliability coefficient for Likert-type scales, (1992), 82-88.

Gounaris, S. (2005). Measuring service quality in b2b services: an evaluation of the SERVQUAL scale vis-àvis the INDSERV scale. Journal of Services Marketing, 19(6), 421-435.

https://doi.org/10.1108/08876040510620193

Gronroos, C. (1983). Strategic Management and Marketing in The Service Sector. Cambridge, MA.

Hilmi, M. F., \& Ali, H. M. (2012). Service Quality and Ease-of-Use of a Learning Management System Portal: Perceptions of Distance Learners, 599-602.

Huang, R. T. (2007). Improving the Service Quality of Distance Education. International Journal of Instructional Technology and Distance Learning, 5(4), 21-29.

Hui-feng, F. W. Q. J. (2010). Case Study on Evaluation of Student Perceived Quality of Learning Service in Distance Education - Based on the "Content-Character" Framework and the SERVPERF Method. Modern Educational Technology, 12, 22.

Jain, R., Sinha, G., \& Sahney, S. (2011). Conceptualizing service quality in higher education. Asian Journal on Quality, 12, 296-314. https://doi.org/10.1108/15982681111187128

Jain, S. K., \& Gupta, G. (2004). Measuring Service Quality: SERVQUAL vs. SERVPERF Scales. Vikalpa: The Journal for Decision Makers, 29(2), 25-37. Retrieved from http://search.ebscohost.com/login.aspx?direct=true\&db=bth\&AN=14024712\&site=ehost-live

James, E., \& Benjamin, G. (1988). Public Policy and Private Education in Japan. London: Macmillan. 
Jusoh, A., Omain, S. Z., Abdul Majid, N., \& Shamsuddin, A. S. (2004). Service quality in higher education: Management student's perspective.

Kadir, S. L. S. A., Abdullah, M., \& Agus, A. (2000). On service improvement capacity index: a case study of the public service sector in Malaysia. Total Quality Management, 11(4-6), 837-843.

Kotze, T. G., \& Plessis, P. F. (2003). Students as "co-producers" of education: a proposed model of student socialisation and participation at tertiary instituitions. Quality Assurance in Eaucation, 11, 186-201.

Le Blanc, G., \& Nguyen, N. (1999). Listening to the customer's voice: examining perceived service value among business college students. The International Journal of Educational Management, 13, 187198.

Lizzio, A., Wilson, K., \& Simons, R. (2002). University Students' Perceptions of the Learning Environment and Academic Outcomes: implications for theory and practice. Studies in Higher Education, 27(27).

Mazumder, Q. H. (2014). Analysis of Quality in Public and Private Universities in Bangladesh and USA. International Journal of Evaluation and Research in Education, 3(2), 99-108.

Ministry of Education Malaysia. (2014). National Education Statistic:Higher education Sector 2013. Ministry of Education Malaysia. Retrieved from http://www.moe.gov.my/cms/upload_files/publicationfile/2014/pubfile_file_002043.pdf

Moisescu, O. I., \& Gica, O. A. (2013). SERVQUAL Versus SERVPERF: Modeling Customer Satisfaction and Loyalty as a Function of Service Quality in Travel Agencies. Studia Universitatis Babes-Bolyai, 58(3), 3-19.

Molesworth, M., Nixon, E., \& Scullion, R. (2009). Having, being and higher education: the marketisation of the university and the transformation of the student into consumer. Teaching in Higher Education, 14, 277-287.

Myers, R. H. (1990). (1990), Classical and Modern Regression With Applications, (2nd ed.). Boston, MA.: PWS-KENT.

Parasuraman, A., Zeithaml, V., \& Berry, L. (1985). A conceptual model of service quality and its implications for future research. Journal of Marketing, 49, 41-50.

Parasuraman, A., Zeithaml, V., \& Berry, L. (1988). SERVQUAL: a multiple-item scale for measuring customer perceptions of service quality. Journal of Retailing, 64, 12-40.

Park, A. R., \& Ha, H. (2013). Comparative analysis of methodologies to evaluate air cargo carriers' service quality: Focusing on SERVQUAL and SERVPERF. Journal of International Logistics and Trade, $11(2), 29-40-46$.

Peters, T. J., Waterman, R. H., \& Jones, I. (1982). In search of excellence: Lessons from America's best-run companies.

Picciano, A. G. (2002). Beyond student perceptions: issues of interaction, presence, and performance in an online course. Journal of Asynchronous Learning Networks, 6, 21-40.

Poon, W., Low, K. L., \& Yong, D. G. (2004). A study of Web-based learning (WBL) environment in Malaysia,. The International Journal of Educational Management, 18(6), 374-385.

Raemah, A. H., \& Rosli, M. (2011). Comparing Commitment to Service Quality Among Academic Staffs' in Private and Public Malaysian Universities. Journal of International Management Studies, 6(1), 1-8. 
Rashid, Z. A., \& Latif, L. A. (2004). Perceived Service Quality and Satisfaction in Distance Education, 1-16.

Redding, P. (2005). The evolving interpretations of customers in higher education: empowering the elusive. International Journal of Consumer Studies, 29, 409-417.

Rigotti, S., \& Pitt, L. (1992). SERVQUAL as a measuring instrument for service provider gaps in business schools. Management Research News, 15(3), 9-17.

Romero, L., \& Rey, E. (2004a). Competition between public and private universities: quality, prices and exams. Economics Series 23, (November). Retrieved from http://earchivo.uc3m.es:8080/handle/10016/329

Romero, L., \& Rey, E. (2004b). Competition between public and private universities: quality, prices and exams. Economics Series 23, (November).

San, N. M. (2010). Impact of Service Quality, Satisfaction, and Personal Factors on Students in Open Distance Learning Institutions in Malaysia. Open University Malaysia.

Sander, P., \& Sanders, L. (2003). Measuring confidence in academic study: A summary report. Electronic Journal of Research in Educational Psychology, 5-3, 113-130.

Sander, P., Stevenson, K., King, M., \& Coates, D. (2000). University Students' Expectations of Teaching. Studies in Higher Education, 25, 309-323.

Sim, H. K. C., \& Idrus, R. M. (2003). Student Satisfaction in Malaysia: Customer-focused learner support. The Asian Society of Open and Distance Education, 1(1), 69-77.

Simonson, M., Schlosser, C., \& Orellana, A. (2011). Distance education research: A review of the literature. Journal of Computing in Higher Education, 23(2-3), 124-142. https://doi.org/10.1007/s12528-0119045-8

Stodnick, M., \& Rogers, P. (2008). Using SERVQUAL to measure the quality of the classroom experience. Decision Sciences Journal of Innovative Education, 6(1), 115-133.

Sultan, P., \& Yin Wong, H. (2010). Service quality in higher education - a review and research agenda. International Journal of Quality and Service Sciences, 2(2), 259-272. https://doi.org/10.1108/17566691011057393

Syson, F. (2008). The student as coproducer of their own education: a service marketing perspective. Conference of the CLTR: Transitions and Transformations Developing Learners and Learning Environments.

Taner, T., \& Antony, J. (2006). Comparing public and private hospital care service quality in Turkey. Leadership in Health Services, 19, 1-10.

Tapscott, D., \& Williams, A. D. (2010). Innovating the 21 st Century University: It's Time. EDUCAUSE Review, 45, 16-29.

Tayyab, M. H., \& Rajput, A. (2014). Service Quality Orientation with Customer Satisfaction and Customer Loyalty Revisited Through Literature. Middle-East Journal of Scientific Research, 21(3), 550-555. https://doi.org/10.5829/idosi.mejsr.2014.21.03.21137

Telford, R., \& Masson, R. (2015). The congruence of quality values in higher education. Quality Assurance in Education, 13, 107-119.

Tenth Malaysia Plan 2011-2015. http://www.pmo.gov.my/dokumenattached/RMK/RMK10_E.pdf 
Terpstra, D. E., \& Honoree, A. L. (2009). The effects of different teaching, research, and service emphases on individual and organizational outcomes in higher education institutions. Journal of Education for Business, 84, 169-176.

Tilak, J. B. G. (1991). The privatisation of higher education. Prospects, XXI(2), 227-239.

Udo, G. J., Bagchi, K. K., \& Kirs, P. J. (2011). Using SERVQUAL to assess the quality of e-learning experience. Computers in Human Behavior, 27(3), 1272-1283. https://doi.org/10.1016/j.chb.2011.01.009

Vinzant, J. C. (1996). Strategic Management and Total Quality Management: Challenges and Choices. Public Administration Quarterly, 20(2), 201-219.

Voss, R., Gruber, T., \& Szmigin, I. (2007). Service quality in higher education: The role of student expectations. Journal of Business Research, 60, 949-959.

Wilkinson, R., \& Yussof, I. (2005). Public and Private Provision of Higher Education in Malaysia: A Comparative Analysis. Higher Education, 50(3), 361-386. https://doi.org/10.1007/s10734-0046354-0

Woodall, T., Hiller, A., \& Resnick, S. (2014). Making sense of higher education: students as consumers and the value of the university experience. Studies in Higher Education, 39(1), 48-67.

Zaibaf, M., Taherikia, F., \& Fakharian, M. (2013). Effect of Perceived Service Quality on Customer Satisfaction in Hospitality Industry: Gronroos' Service Quality Model Development. Journal of Hospitality Marketing \& Management, 22(5), 490-504. https://doi.org/10.1080/19368623.2012.670893

Zeithaml, V. A. (1988). of Consumer Perceptions A Means-End Value: Quality, and and Model Synthesis of Evidence, 52(July), 2-22.

Zeithaml, V., Bitner, M., \& Gremler, D. (2006). Services Marketing - Integrating Customer Focus across the Firm. New York: McGraw-Hill 